\title{
Taxonomic structure of local floras in Sidinskiy and Pribaitakskiy steppes (Krasnoyarsk region)
}

\author{
Ekaterina Antipova*, Olga Enulenko \\ Krasnoyarsk State Pedagogical University named after V. P. Astafiev, Ada Lebedeva Str., 89, \\ Krasnoyarsk, 660049, Russia
}

\begin{abstract}
Sidinskiy and Pribaitakskiy steppes are the part of the Minusinsk province of the Altai-Sayan mountain country. On the territory of steppes 12 local floras (LF) were marked and examined using the same method. Studies were carried out according to the recommendations of A.I. Tolmachev (1931): identification of different types of ecotypes of LF, the full species composition of ecotypes (flora inventory), tracking the completeness of detection in LF. In the Sidinskiy steppe the number of families in the LF varies from 25 (Syida) to 43 (v. Alha), in the Pribaitakskiy steppe there is a big difference in the number of families in the LF from 31 (Krasnoyarsk reservoir, Tuba) to 65 (Mayak, Idra). The leading families in the local steppe flora are Asteraceae, Poaceae, Fabaceae. The Fabaceae family ranks third in the top of ten families in 50 $\%$ of LF, determining the type of flora as the Mediterranean-Central Asian (Fabaceae-type). Different types of LF allow to determine the type of all steppe flora as mixed, combining features of boreal (Asteraceae-Poaceaetype) and steppes flora (Fabaceae-type) with close ties with Central European floras (Rosaceae-type). 4 distinct levels of species richness are determined: 1 - 496-544; 2 - 408-413; 3 - 319-374; 4 - 279-298 species.
\end{abstract}

Sidinskiy and Pribaitakskiy steppes are located in the Sydo-Yerbin Basin, are a part of the Minusinsk province of the Altai-Sayan mountain country [1]. Sidinskiy steppe occupies the southern part of Krasnoturanskiy region, Pribaitakskiy steppe covers a part of Krasnoturanskiy, Idrinskiy and Kuraginskiy areas of the Krasnoyarsk region.

On the territory of steppes 12 local floras (LF) were marked and examined using a single method. These LF are samples of flora [2-4] and are representing the main variety of partial floras in the vicinity of the studied geographical points. Studies were carried out according to the recommendations of A. I. Tolmachev [5], which implies equal completeness of the study of local floras: identification of different types of ecotypes of LF, the full species composition of ecotypes (flora inventory), tracking the completeness of detection in LF.

Comparing studied steppes LF, revealed different levels of floristic richness associated with landscape, environmental and edaphic features, as well as the difference in their areas. Pribaitakskiy steppe is superior then Sidinskiy one by area and the number of studied local floras: 3 LF - in Sidinskiy and 9 in Pribaitakskiy steppes (table 1).

\footnotetext{
* Corresponding author: katusha05@bk.ru
} 
Table 1. Parameters of local floras in Sidinskiy and Pribaitakskiy steppes

\begin{tabular}{|c|c|c|c|c|c|c|c|}
\hline \multirow[b]{2}{*}{$\mathbf{L F}$} & \multicolumn{3}{|c|}{$\begin{array}{l}\text { The composition of the } \\
\text { flora }\end{array}$} & \multicolumn{2}{|c|}{$\begin{array}{l}10 \text { leading families of } \\
\text { LF }\end{array}$} & \multicolumn{2}{|c|}{$\begin{array}{l}\text { Monospecific } \\
\text { families of LF }\end{array}$} \\
\hline & $\begin{array}{l}\text { familie } \\
\text { s of } L F\end{array}$ & $\begin{array}{l}\text { genus } \\
\text { of } L F\end{array}$ & $\begin{array}{l}\text { species } \\
\text { of } L F\end{array}$ & $\begin{array}{c}\text { the } \\
\text { absolute } \\
\text { number } \\
\text { of } \\
\text { species }\end{array}$ & $\begin{array}{c}\text { percent } \\
\text { compositio } \\
n \text { of the } \\
\text { total } \\
\text { number of } \\
\text { species }\end{array}$ & $\begin{array}{c}\text { the } \\
\text { absolut } \\
\text { e } \\
\text { number } \\
\text { of } \\
\text { species }\end{array}$ & $\begin{array}{c}\text { percent } \\
\text { compositi } \\
\text { on of the } \\
\text { total } \\
\text { number of } \\
\text { species }\end{array}$ \\
\hline \multicolumn{8}{|c|}{ Sidinskiy } \\
\hline Al & 43 & 202 & 349 & 228 & 65,3 & 17 & 1,7 \\
\hline Un & 42 & 122 & 413 & 245 & 59,3 & 14 & 1,4 \\
\hline Sd & 25 & 59 & 279 & 159 & 57,0 & 10 & 1 \\
\hline \multicolumn{8}{|c|}{ Pribaitakskiy steppe } \\
\hline Mk & 65 & 272 & 544 & 378 & 69,4 & 21 & 2,1 \\
\hline $\mathbf{K b}$ & 49 & 139 & 419 & 241 & 57,5 & 20 & 2 \\
\hline Tu & 64 & 237 & 496 & 406 & 81,8 & 27 & 2,7 \\
\hline Lo & 33 & 74 & 298 & 221 & 74,2 & 17 & 1,7 \\
\hline Id & 65 & 232 & 408 & 366 & 89,7 & 29 & 2,9 \\
\hline Bs & 37 & 102 & 368 & 218 & 59,2 & 11 & 1,1 \\
\hline $\mathbf{K u}$ & 47 & 183 & 365 & 222 & 60,8 & 19 & 1,9 \\
\hline $\mathbf{K v}$ & 31 & 111 & 374 & 225 & 60,1 & 9 & 0,9 \\
\hline Tb & 31 & 95 & 316 & 243 & 76,9 & 3 & 0,3 \\
\hline In total: & 102 & 365 & 994 & 603 & 60,3 & 38 & 3,8 \\
\hline
\end{tabular}

Note. LF - local floras; Al - v. Alha, Un - v. Unyuk, Sd - Syida, Mk - city Mayak, Kb Krasnoturanskiy Bor, Tu - city Turan, Lo - lake Lebyazhye, Id - Idrinskoe, Bs - Big Salba, Ku Kuragino, $\mathrm{Kv}$ - Krasnoyarsk water reservoir, $\mathrm{Tb}-$ Tuba.

The largest number of families and genus are represented in local floras with a combination of flat and mountain landscapes. In the Sidinskiy steppe the number of families in the LF varies from 25 (Syida) to 43 (v. Alha), the richest LF of Unyuk. An equally large difference in the composition of the steppe genus (59-202) is explained by local orography conditions - the presence of v. Alha, Unyuk, river Syida with its valleys and the Syidin Bay of the Krasnoyarsk water reservoir. Syida local flora is isolated by the Syidin Bay and includes a large number of intrazonal vegetation communities, therefore, contains the smallest number of families and genus (table 1).

In the Pribaitakskiy steppe there is a big difference in the number of families in the LF from 31 (Krasnoyarsk reservoir, Tuba) to 65 (Mayak, Idra) and genus (from 74 (lake Lebyazhye) to 272 (Mayak), due not only to the hilly-flat terrain, rich network of rivers with swampy depressions, where steppe, meadow, water and wetland vegetation is the most fully represented, but also a combination of pronounced latitudinal zoning and altitudinal zoning, manifested in concentric zoning. In the Central part of the Pribaitakskiy steppe local flora of Turan, Mayak, Krasnoturanskiy bor forms the "steppe core", surrounded by meadow steppes wide striped on the periphery.

The leading families in the local steppe flora are Asteraceae, Poaceae, Fabaceae. In taxonomic spectras $12 \mathrm{LF}$ (table 2) the coincidence of the set of leading families is a characteristic only for 2 LF. All LF take first and second place of the family Asteraceae and Poaceae, except for the LF Syida, where they change their places. These are the largest families for the flora of the entire globe, as well as for all areas of the Holarctic (with the exception of the Arctic regions) [6]. This pattern is reflected in all local floras studied steppes. 
The Fabaceae family ranks third in the top of ten families in $50 \%$ of LF (Alha, Turan, lake Lebyazhye, Kuragino and Krasnoyarsk water reservoir) with high species richness (1739), determining the type of flora as the Mediterranean-Central Asian (Fabaceae-type). This is a manifestation of the ancient "southern" links with the formation of the secondary center of species spreading in the steppes [6-9]. The remaining LF belong to different types: 3 LF (Maiak, Krasnoturansky Bor, Idra) are characterized by close ties with the Central European flora (Rosaceae-type) with the manifestation of features of climate humidity. The local flora of Tuba bears the features of the middle Eastern and Eurasian floras with a hilly meadow, forest-meadow and meadow-marsh gradient (Ranunculaceae-type). Local flora Big Salba is defined as Arctoboreal-East-Asia-combined, which combines features of boreal and steppe floras. The local flora of Unyuk bears the features of Alpine-meadow flora with the European bias and influence of species of anthropogenic flora (Brassicaceaetype).

Thus, the families of the leading part of the taxonomic spectrum of LF are associated with their zonal and subzonal position, as well as the alternation of humid and arid habitats in the steppes. The set of families leading by the number of species corresponds to the geographical position of the steppes, reflecting the main features of the boreal flora (predominance of families Asteraceae, Poaceae, Rosaceae, Ranunculaceae, Cyperaceae) with an ancient Mediterranean bias. High ranks make up the family (Fabaceae, Lamiaceae, Apiaceae) due to migration of species from neighboring floristic regions of Kazakhstan and Central Asia. In the majority of the LF mixed migratory species are dominating. The relative abundance of Eurasian species increases to the Northeast and East of the studied steppes.

Table 2. Leading families of floristic list of local floras Sidinskiy and Pribaitakskiy steppes

\begin{tabular}{|l|c|c|c|c|c|c|c|c|c|c|c|c|}
\hline \multirow{3}{*}{ Families } & \multicolumn{10}{|c|}{ Local floras } \\
\cline { 2 - 14 } & $\mathrm{Al}$ & $\mathrm{Un}$ & $\mathrm{Sd}$ & $\mathrm{Mk}$ & $\mathrm{Kb}$ & $\mathrm{Tu}$ & $\mathrm{Lo}$ & $\mathrm{Id}$ & $\mathrm{Bs}$ & $\mathrm{Ku}$ & $\mathrm{Kv}$ & $\mathrm{Tb}$ \\
\hline Asteraceae & $54 / 1$ & $42 / 1$ & $34 / 2$ & $138 / 1$ & $97 / 1$ & $72 / 1$ & $36 / 1$ & $86 / 1$ & $57 / 1$ & $87 / 1$ & $37 / 1$ & $46 / 1$ \\
\hline Poaceae & $42 / 2$ & $39 / 2$ & $49 / 1$ & $63 / 2$ & $73 / 2$ & $43 / 2$ & $28 / 2$ & $44 / 2$ & $43 / 2$ & $58 / 2$ & $25 / 2$ & $38 / 2$ \\
\hline Fabaceae & $20 / 3$ & $20 / 4$ & $16 / 3$ & $38 / 4$ & $22 / 4$ & $39 / 3$ & $17 / 3$ & $29 / 4$ & $15 / 5$ & $29 / 3$ & $17 / 3$ & $15 / 5$ \\
\hline Rosaceae & $17 / 6$ & $11 / 6$ & $10 / 6$ & $43 / 3$ & $34 / 3$ & $34 / 4$ & $11 / 4$ & $32 / 3$ & $14 / 7$ & $15 / 5$ & $10 / 8$ & $9 / 7$ \\
\hline Ranunculaceae & $18 / 5$ & $18 / 5$ & $14 / 5$ & $33 / 5$ & $19 / 5$ & $19 / 6$ & $9 / 7$ & $22 / 6$ & $17 / 4$ & $14 / 6$ & $9 / 9$ & $36 / 3$ \\
\hline Brassicaceae & $19 / 4$ & $22 / 3$ & $9 / 7$ & $33 / 6$ & $12 / 8$ & $19 / 7$ & $9 / 8$ & $22 / 7$ & $15 / 6$ & $14 / 7$ & $15 / 4$ & $9 / 8$ \\
\hline Lamiaceae & $12 / 7$ & $10 / 8$ & $5 / 8$ & $16 / 9$ & $14 / 7$ & $23 / 5$ & $4 / 9$ & $18 / 10$ & $9 / 9$ & $14 / 8$ & $15 / 5$ & $8 / 9$ \\
\hline Polygonaceae & $8 / 8$ & $11 / 7$ & $5 / 9$ & $16 / 10$ & $12 / 9$ & $15 / 8$ & -- & $20 / 9$ & -- & -- & $12 / 6$ & -- \\
\hline Cyperaceae & $6 / 10$ & $8 / 10$ & $16 / 4$ & $26 / 7$ & $16 / 6$ & $8 / 10$ & $8 / 6$ & $23 / 5$ & $18 / 3$ & $14 / 9$ & $12 / 7$ & $27 / 4$ \\
\hline Apiaceae & $7 / 9$ & $9 / 9$ & -- & $18 / 8$ & $5 / 10$ & $12 / 9$ & $11 / 5$ & $21 / 8$ & $12 / 8$ & $17 / 4$ & $9 / 10$ & $10 / 6$ \\
\hline
\end{tabular}

Note. Absolute number of vascular plant species in the family/ number of family place descending.

Different types of LF allow to determine the type of all steppe flora as mixed, combining features of boreal (Asteraceae-Poaceae-type) and steppes flora (Fabaceae-type) with close ties with Central European floras (Rosaceae-type).

The amplitude and the course of change in the number of LF species in the compared steppes is different. 4 distinct levels of species richness are determined: $1-496-544 ; 2-$ 408-413; 3 - 319-374; 4 - 279-298 species (table 2). 


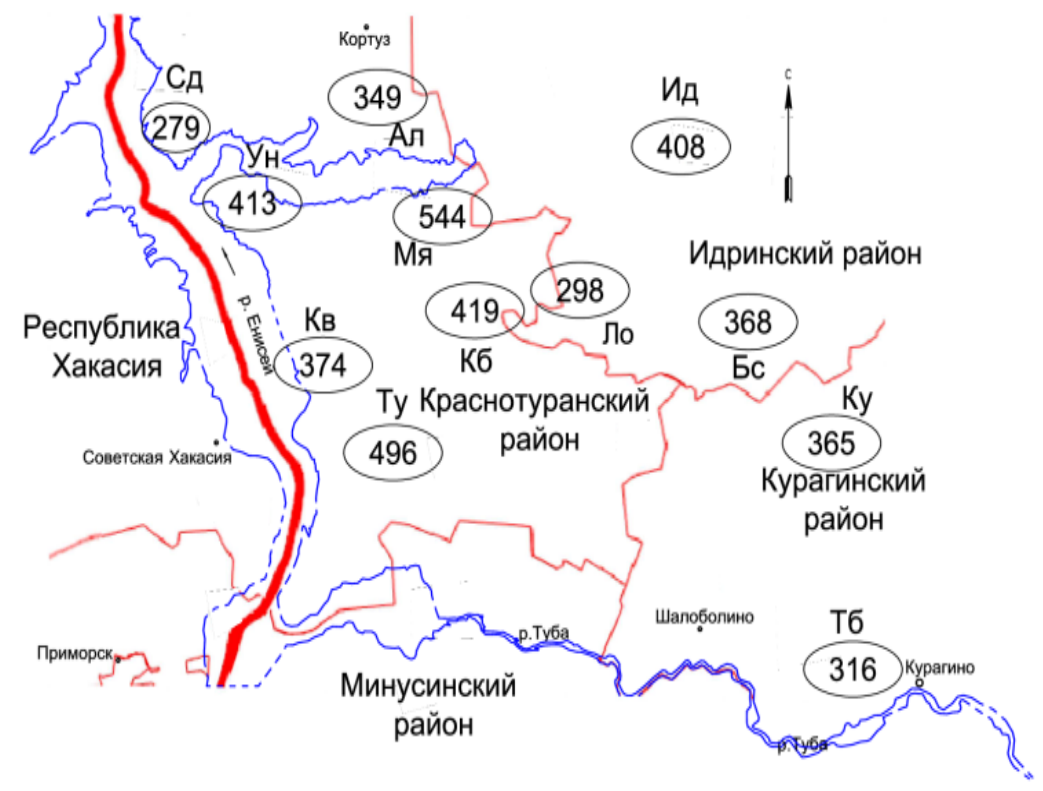

Fig. Species diversity in local floras Sidinskiy and Pribaitakskiy steppes (in the circles is the number of species). Decoding of local floras names is given in table 1.

In the Sidinskiy steppes on the level of species richness allocated LF Alha and Unyuk, in the Pribaitakskiy steppes -LF Mayak, Idra, Krasnoturanskiy Bor, according to the nature of the vegetation cover attributed by L. M. Cherepnin [10] to the subzone meadow steppes (southern steppes), which combines steppes, forest-steppes and meadow species. The value of more than 500 species (544) was observed only in the Central border point between Sidinskiy and Pribaitakskiy steppes - in the local flora Mayak.

The level of species diversity increases from North to South and from West to East and North-East, as well as from the periphery to the center of the studied flora (Illustration) that is associated with the increase in the continentally of climate in these areas, concentric zoning, which often overlaps with macromosaic, a variety of antopia and enclaves of "southern" vegetation.

Acknowledgement: the Study was carried out with the financial support of the Russian Foundation for basic research, the Government of the Krasnoyarsk territory, the Krasnoyarsk regional Science Foundation in the framework of the scientific project 18-44240006 "Natural and urbanized flora of the Yenisei Siberia".

\section{References}

1. Yu.A. Sherbakov, M.V. Kirillov, Sib. geographer. team, 1 (1962)

2. B.A. Yurtsev, Bulletin of MOIP, 87, 4 (1982)

3. E.M. Antipova, The flora of the Northern forest-steppes of Middle Siberia, Diss. (Tomsk, 2008)

4. E.M. Antipova, Comparative Floristic: Materials of all-Russian school-seminar on comparative Floristic, 2, 2 (2010)

5. A.I. Tolmachev, Journal. Russ. bot. Ls-VA, 16, 1 ( 1931)

6. A.P. Hohryakov, Bot. journal, 85, 5 (2000) 
7. A.V. Polozhii, Flora of Krasnoyarsk region: Fabaceae, 6 (Tomsk, Tomsk state University; Novosibirsk, Science, 1960)

8. A.I. Tolmachev, Introduction to the geography of plants (L., publishing House of LSU, 1974)

9. A.I. Tolmachev, Methods of comparative Floristics and problems of florogenesis (Novosibirsk, Science, 1986)

10. L.M. Cherepnin, Flora and vegetation of the southern part of Krasnoyarsk region, Diss. (L., BIN AN SSSR, 1953) 